\title{
Systemy umożliwiające identyfikację upadku z wysokości
}

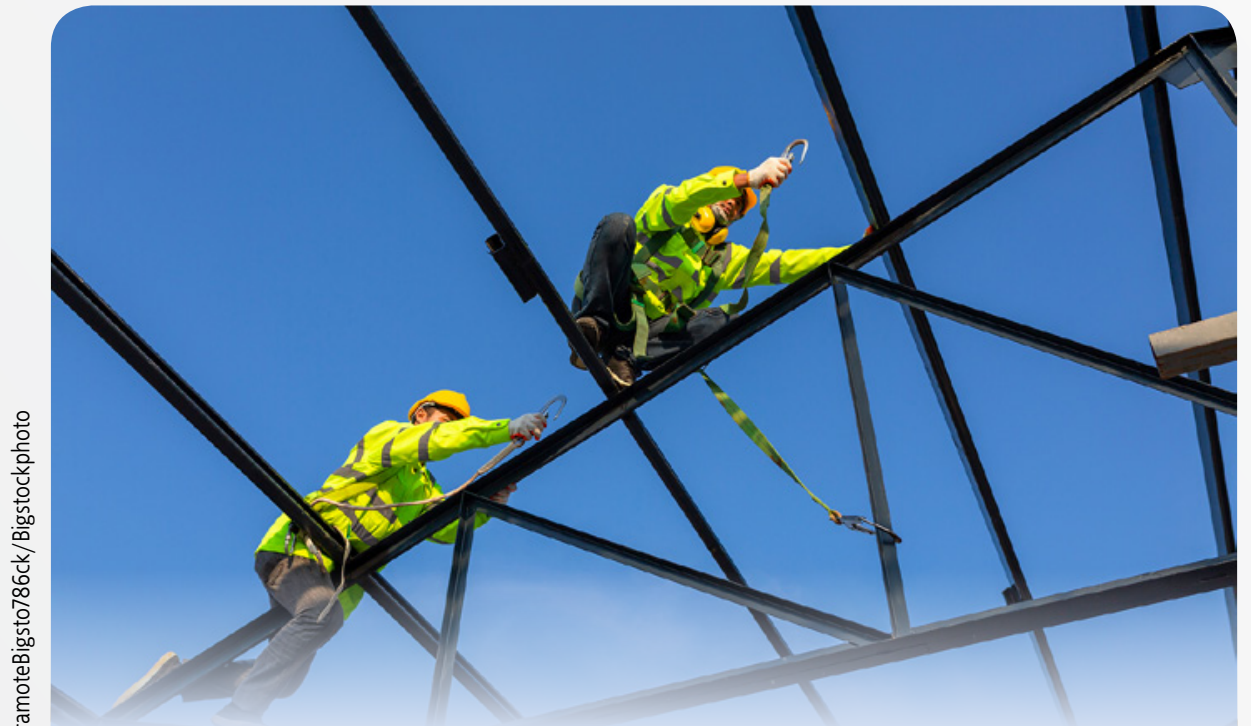

W artykule omówiono dwa rodzaje opracowanych w CIOP-PIB systemów umożliwiających identyfikację upadku człowieka z wysokości. Działanie pierwszego z nich jest oparte na akcelerometrycznym układzie pomiarowym, zaimplementowanym w pasie biodrowym, który stanowi element sprzętu zabezpieczającego przed upadkiem z wysokości. Działanie drugiego systemu polega na analizie zarejestrowanego obrazu wideo. Przedstawiono metody oraz wyniki badań kalibracyjnych i sprawdzających obu zaprojektowanych systemów, które wykorzystano do przeprowadzenia badań wstępnych. Podczas tych badań uczestnik wykonywał określone ćwiczenia: siadanie i symulowany upadek. Porównanie wyników badań wykazało dużą zbieżność pomiędzy wartościami zmierzonymi za pomocą czujników przyspieszeń oraz wartościami uzyskanymi na podstawie przeprowadzonej analizy obrazu. Opisane systemy mogą więc posłużyć do identyfikacji upadku oraz jako elementy inicjujące urządzenia do dynamicznego skracania drogi spadania, które zmniejszą siły działające na człowieka podczas powstrzymywania jego spadania z wysokości.

Słowa kluczowe: upadek z wysokości, akcelerometryczne układy pomiarowe, analiza obrazu wideo, skracanie drogi spadania

\section{Systems for identifying falls from a height}

The article discusses two types of systems developed at CIOP-PIB, which enable the identification of human falls from a height. The operation of the first system is based on an accelerometric measuring system implemented in the hip belt, which is an element of the equipment protecting against falls from a height. The operation of the second system is based on the analysis of the recorded video. The methods and results of calibration and verification tests of both designed systems, which were used for the preliminary tests, were presented. During these tests, the participant performed specific exercises: sitting down and simulating falling. The comparison of the test results showed a high convergence between the values measured with the acceleration sensors and the values obtained on the basis of the image analysis. The described systems can therefore be used for fall identification and as initiators of devices for dynamic shortening of the fall path, which will reduce the forces acting on a person during restraining his fall from a height. Keywords: falls from a height, accelerometric measuring systems, analysis of the recorded video, shortening of the fall path

\section{Wstęp}

Identyfikacja upadków była wielokrotnie przedmiotem badań naukowych i projektów technicznych [1-6]. Zasadniczo rozwiązania techniczne w tym zakresie można podzielić na trzy główne klasy: urządzenia noszone na ciele, urządzenia otoczenia i urządzenia oparte na rejestracji obrazu. Pierwsza z nich wymaga, aby osoby monitorowane nosiły na ciele takie urządzenia wyposażone w czujniki, jak: akcelerometry, żyroskopy czy inklinometry [7-10]. Rozwój tego typu urządzeń jest możliwy dzięki postępującej miniaturyzacji, redukcji kosztów akcelerometrów oraz dostępności niezawodnych technologii komunikacji bezprzewodowej [11-14]. Kolejne klasy rozwiązań wymagają obecności systemów pomiarowych w środowisku pracy.

Wykorzystywanie czujników przyspieszeń jako głównych narzędzi pomiarowych do monitorowania różnych rodzajów ludzkiego ruchu - w tym do identyfikacji upadku - było stosowane na szeroką skalę już od drugiej połowy XX w., m.in. do pomiaru wydatku energii metabolicznej, poziomu aktywności fizycznej, równowagi i kołysania pozycyjnego oraz chodu [15]. Podstawowe podejście, polegające na wykorzystaniu akcelerometrii do identyfikowania upadków na podłoże, zostało opublikowane dopiero pod koniec XX w. $[16,17]$. W tym podejściu jako upadek zdefiniowano zmianę orientacji ciała z wyprostowanej na leżącą, która następuje bezpośrednio po dużym ujemnym przyspieszeniu. Te dwa warunki zostały włączone do algorytmów wykrywania upadku za pomocą akcelerometrów [18, 19]. W celu zapewnienia niezawodnego działania systemów wykrywania upadku należy uwzględnić towarzyszące mu zjawiska i zminimalizować liczbę wyników fałszywie pozytywnych (tzn. będących efektem zidentyfikowania przez czujniki upadku, mimo że faktycznie do niego nie doszło), związanych z powszechną aktywnością człowieka, taką jak chodzenie, siadanie czy skłony.

Wykrywanie upadków za pomocą sprzętu do rejestracji obrazu [20-23] opiera się na wykorzystaniu pojedynczych kamer CCD (ang. charge-coupled device) [23-25], wielokrotnych kamer [26], specjalistycznych kamer wielokierunkowych [27], stereopar [28] oraz kamer głębi i radarów impulsowych [29]. Te rozwiązania oprócz wielu zalet - takich jak: możliwość detekcji różnych czynności, mała inwazyjność i możliwość zdalnej weryfikacji zdarzeń upadku oraz 
a)

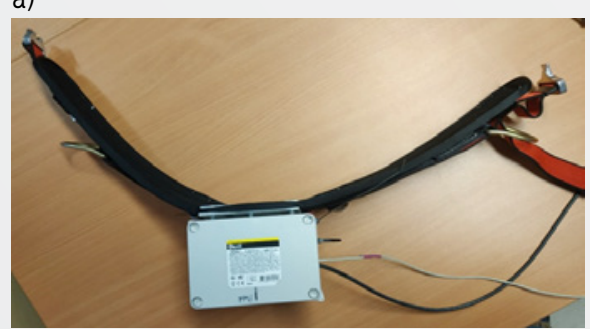

b)

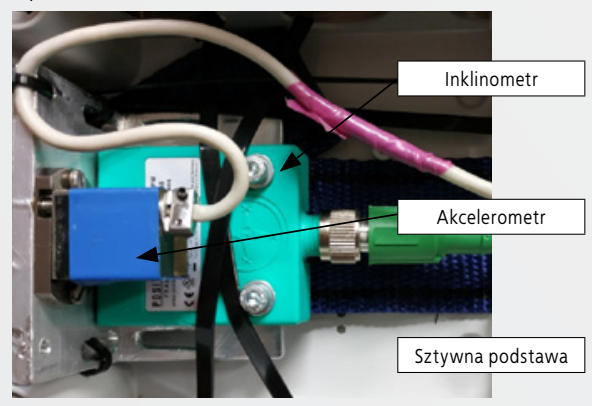

Rys. 1. Zestaw do pomiaru przyspieszenia i kąta: a) widok zestawu pomiarowego z pasem biodrowym, b) widok czujników zamontowanych wewnątrz obudowy

Fig. 1. Set for measuring acceleration and deflection angle: a) view of the measuring set with the waist belt, b) view of sensors mounted inside the housing

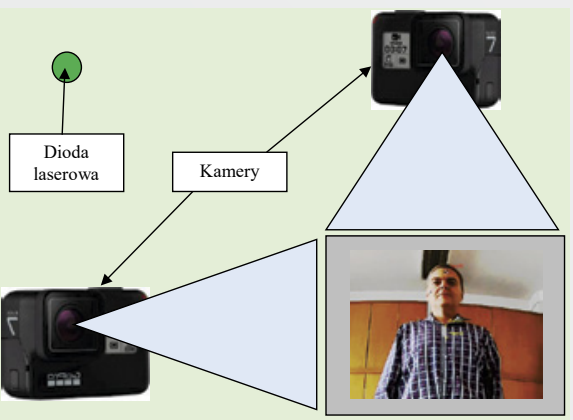

Rys. 2. Schemat dodatkowego zestawu pomiarowego do rejestracji obrazu wideo

Fig. 2. Scheme of an additional measuring set for video recording

bezbłędna identyfikacja „zwykłych” czynności-mają także wady, do których zalicza się: długi czas instalacji i kalibracji, wysoką cenę, konieczność użycia dodatkowego komputera PC lub notebooka do przetwarzania obrazu, ograniczone zastosowanie w warunkach nocnych lub przy słabym oświetleniu oraz brak głębokości obrazu. Wymienione wady sąjednak w sposób ciągły eliminowane dzięki postępowi technologicznemu.

Celem publikacji jest przedstawienie systemów umożliwiających identyfikację upadku człowieka. Takie systemy (i przekazywane przez nie informacje) są przydatne m.in. dla producentów sprzętu chroniącego przed upadkiem z wysokości. Mogą być użyte np. jako aktywatory inicjujące urządzenia do dynamicznego skracania drogi spadania.

\section{Akcelerometryczny system pomiarowy}

W ramach projektu badawczego zrealizowanego w CIOP-PIB opracowano i zbudowano akcelerometryczny system pomiarowy, składający się z dwóch głównych modułów:

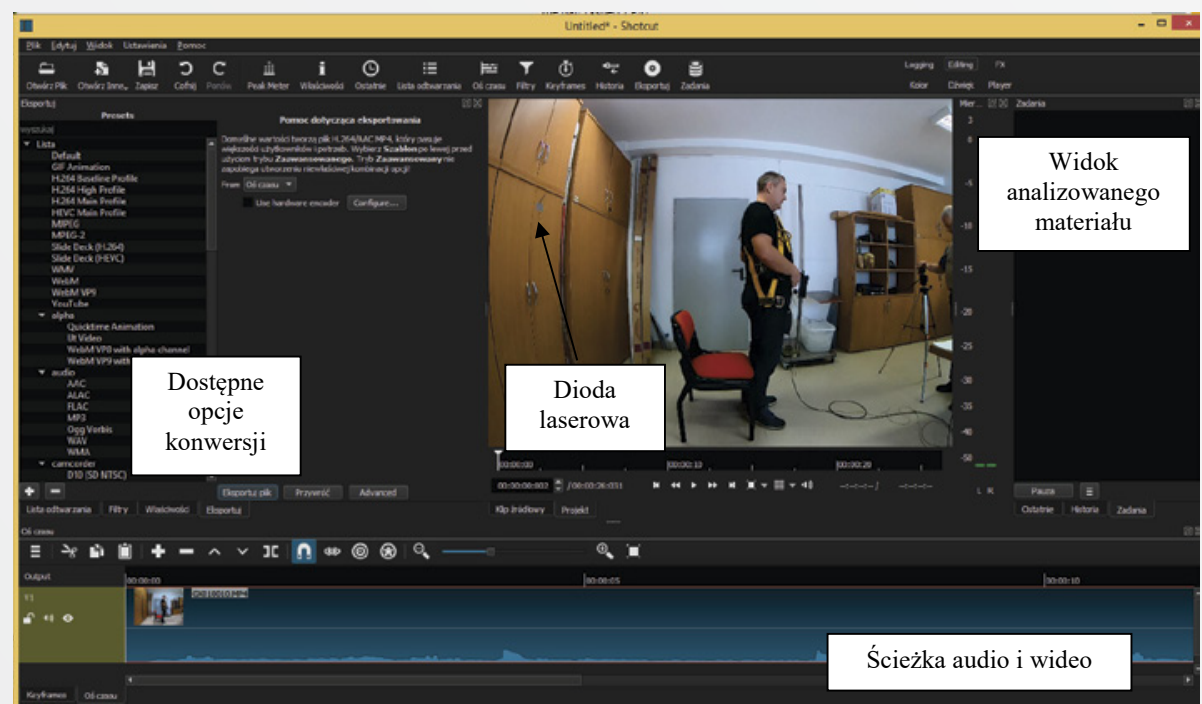

Rys. 3. Konwersja zapisanego materiału wideo do formatu BMP

Fig. 3. Converting recorded video material to BMP format

- części umożliwiającej pomiar przyspieszenia w kierunku pionowym i poziomym oraz pomiar kąta pochylenia względem pionu (wyznaczonego przez kierunek siły grawitacji), w skład której wchodziły 3-osiowy piezorezystywny akcelerometr i inklinometr, umieszczone na sztywnej podstawie (rys. 1.)

- części do zapisu i obróbki zebranych danych, w której skład wchodziły wzmacniacz i zasilacz $10 \mathrm{~V}$. Zestaw pomiarowy umieszczono w obudowie z tworzywa sztucznego, aby zabezpieczyć elementy elektroniczne przed uszkodzeniami. Zapis i obróbkę danych realizowano za pomocą oscyloskopu oraz komputera PC z oprogramowaniem do rejestracji i zapisu mierzonych wielkości.

\section{Uzupełniający system wizyjny}

Opracowano również dodatkowy, uzupełniający wizyjny system pomiarowy. W jego skład wchodziły dwie kamery, ustawione na płaszczyźnie pod kątem $90^{\circ}$ (rys. 2.). Do ich synchronizacji z podstawowym zestawem pomiarowym zastosowano diodę laserową, która była uruchamiana sygnałem wyzwalającym pomiar. Obraz zarejestrowany przez kamery poddawano

cyfrowej obróbce z wykorzystaniem oprogramowania do obróbki materiałów wideo i analizy obrazów.

Materiał wideo, zapisany podczas zaplanowanych ćwiczeń, był „przycinany” i konwertowany do formatu BMP (rys. 3.). Następnie pliki poddawano komputerowej analizie (rys. 4.), polegającej na śledzeniu wybranych punktów obrazu oraz na wyznaczeniu przebytej drogi, prędkości i przyspieszenia.

\section{Kalibracja akcelometrycznego systemu pomiarowego}

Przed pierwszym użyciem gotowy system pomiarowy poddano kalibracji. Wzmocnienie sygnału $z$ akcelerometru ustawiono w taki sposób, aby wartość 1 g odpowiadała wartości napięcia $50 \mathrm{mV}$. Wskazania inklinometru porównano ze wskazaniami wzorcowanej poziomnicy elektronicznej podczas ich jednoczesnego pochylania (co $10^{\circ}$ ) dla kątów w zakresie od $0^{\circ}$ do $80^{\circ}$. Sygnał wyjściowy był w postaci napięcia, gdzie wartość $0,92 \mathrm{~V}$ odpowiadała kątowi $-80^{\circ}, 5,42 \mathrm{~V}-0^{\circ}$, a 9,92 V - $+80^{\circ}$.

Przeprowadzono wstępne badania przyspieszenia i pochylenia kątowego dla siadania oraz upadku

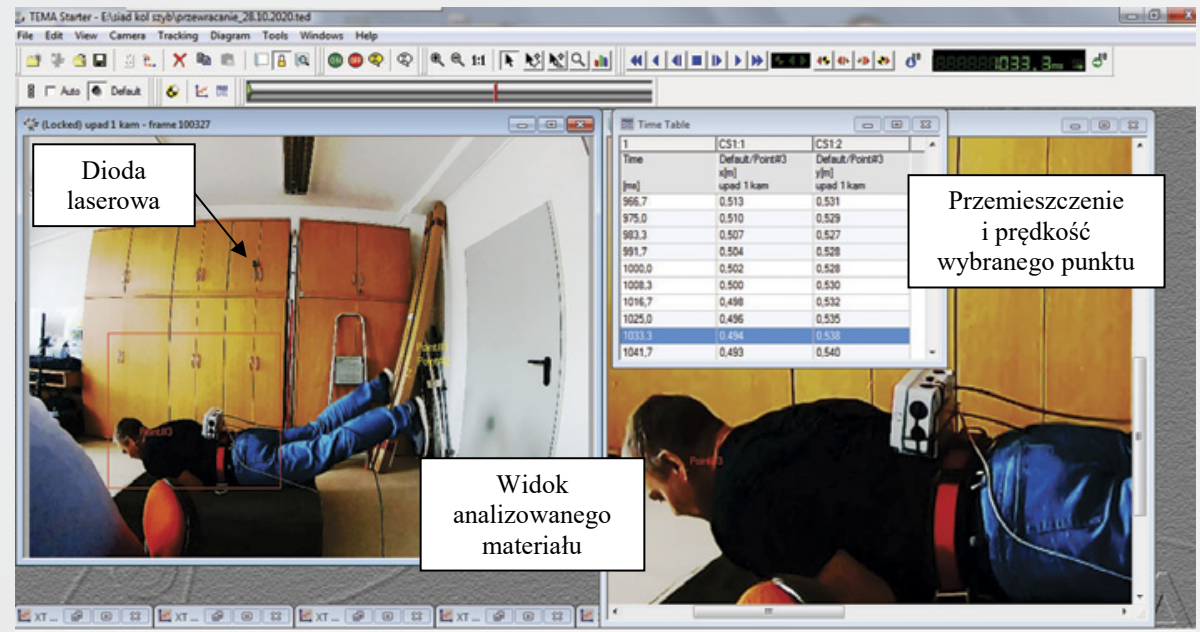

Rys. 4. Analiza zapisanych obrazów wideo

Fig. 4. Analysis of the recorded video images 


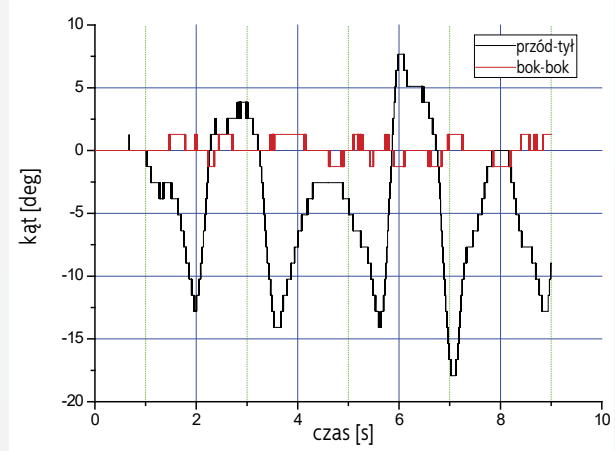

Rys. 5. Wykres pochylenia (kąta) człowieka podczas siadania Fig. 5. Graph of the inclination (angle) of a man making a sit down

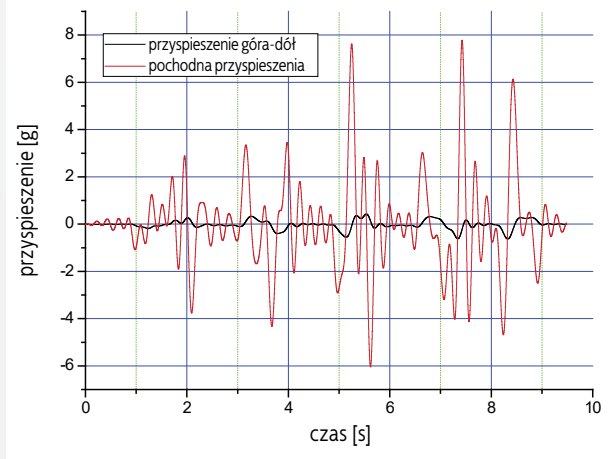

Rys. 6. Wykres przyspieszenia w kierunku góra-dół i jego po chodnej dla siadającego człowieka

Fig. 6. Graph of up-down acceleration and its derivative for a man making a sit down

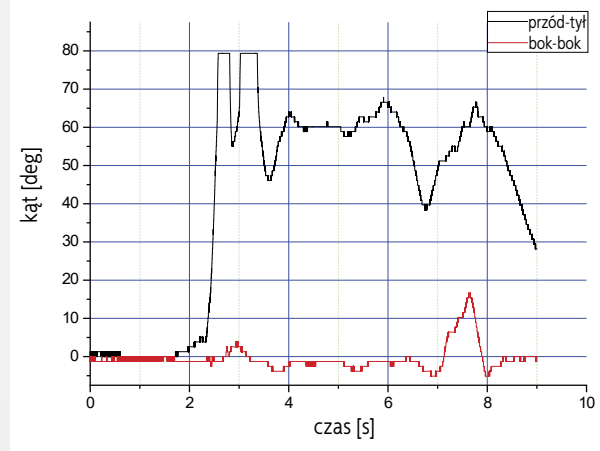

Rys. 7. Wykres pochylenia (kąta) człowieka podczas upadku Fig. 7. Graph of the inclination (angle) of a man during a fall

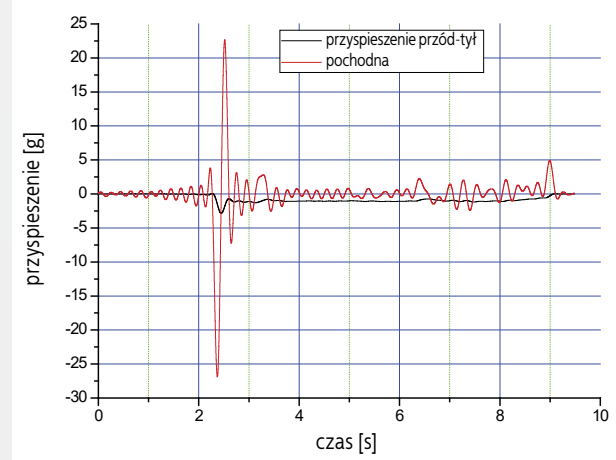

Rys. 8. Wykres przyspieszenia w kierunku przód-tył i jego po chodnej dla człowieka podczas upadku

Fig. 8. Graph of the forward-backward acceleration and its derivative for a man during a fall

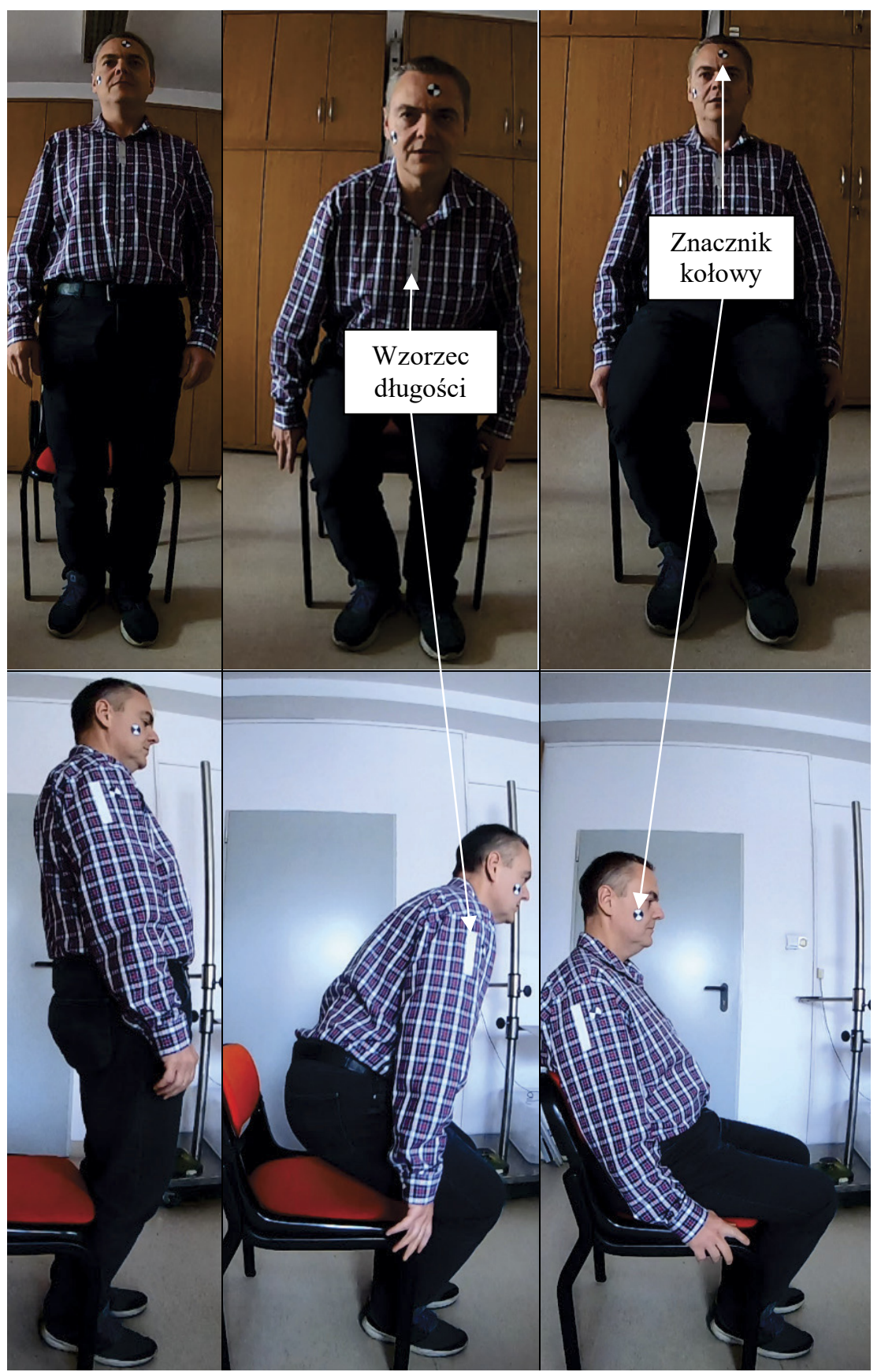

Rys. 9. Zdjęcia faz ruchu podczas siadania

Fig. 9. Pictures of the movement phases of a man making a sit down

człowieka wyposażonego w zestaw pomiarowy umieszczony w okolicy pasa. Przykładowe wyniki pomiarów pochylenia (kąta) w pionowych płaszczyznach człowieka (przód-tył i bok-bok) oraz przyspieszenia w kierunku pionowym (góra-dół) podczas siadania przedstawiono na rys. 5. i 6 ., a wyniki pomiarów pochylenia (kąta) w pionowych płaszczyznach człowieka (przód-tył i bok-bok) oraz przyspieszenia w kierunku poziomym (przód-tył) podczas upadku - na rys. 7. i 8.

\section{Sprawdzenie systemu wizyjnego}

System pomiarowy sprawdzono każdorazowo przed wykonaniem badań. Aby program do analizy ruchu mógł rejestrować przemieszczenie wybranego punktu obrazu, obiekt badań oklejono specjalnie przygotowanymi znacznikami oraz „wzorcem długości". Przeprowadzono rejestrację i obróbkę materiału wideo dla zaplanowanej grupy ćwiczeń.

Przykładowe zdjęcia (z zaznaczonymi wzorcem długości oraz znacznikiem kołowym) poszczególnych faz ruchu podczas siadania, uzyskane z dwóch kamer rejestrujących obraz, przedstawiono na rys. 9.

Na rys. 10. zaprezentowano przykładowe wyniki analizy obrazu oraz identyfikację drogi, prędkości i przyspieszenia wybranych punktów ciała człowieka. 


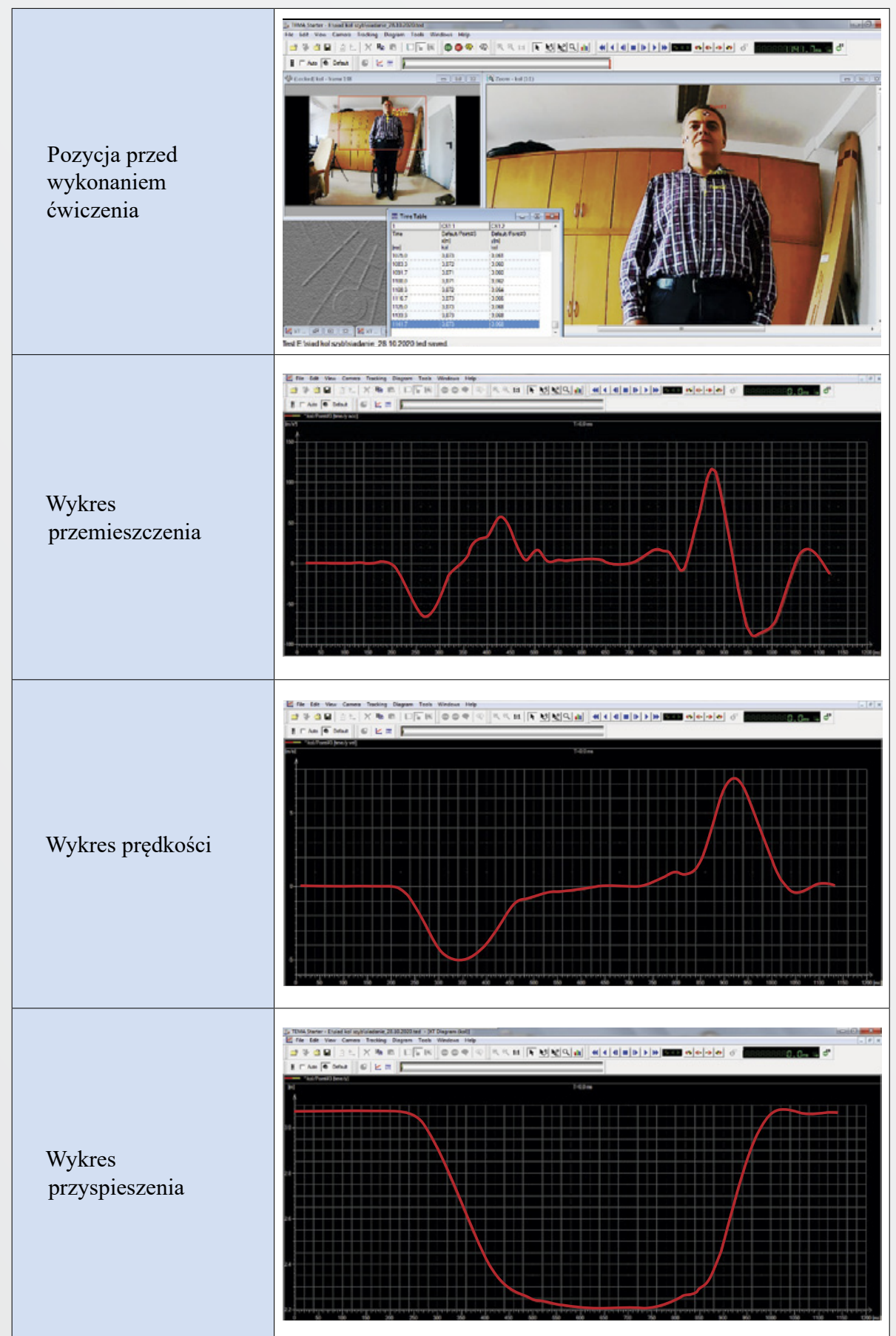

Rys. 10. Wyniki analizy obrazu oraz identyfikacja drogi, prędkości i przyspieszenia siadającego człowieka w kierunku pionowym Fig. 10. Image analysis results and identification of the displacement, velocity and acceleration of a man making a sit down in the vertical direction

W kolejnych tabelach zestawiono następujące wielkości charakteryzujące czynności siadania i upadku z wysokości:

- średnie maksymalne wartości bezwzględne pochylenia (kąta) dla kierunku przód-tył i bok-bok (tab. 1.)

- średnie maksymalne wartości przyspieszenia dla kierunku góra-dół ( $x$ ) (tab. 2.)

- średnie maksymalne wartości przyspieszenia dla kierunku przód-tył (y) (tab. 3.)

- średnie maksymalne wartości narastania przyspieszenia dla kierunku góra-dół $(x)$ (tab. 4.)
Analogicznie najwyższe średnie wartości bezwzględne przyspieszenia podczas upadku były równe 2,8 g, a najniższe podczas siadania nie osiągały 0,8 g. Wartości, które pokazują dynamikę przyspieszenia (pochodna przyspieszenia), jednoznacznie wskazują, że największe maksymalne bezwzględne zmiany, obserwowane podczas upadku, przekraczają $23 \mathrm{~g} / \mathrm{s}$ w każdym rejestrowanym kierunku.

Wyniki wstępnych badań, które przeprowadzono z wykorzystaniem kamer i obróbki cyfrowej materiału wideo, pozwoliły na określenie przyspieszeń ciała człowieka podczas tych samych ćwiczeń i w takich samych kierunkach jak w przypadku pomiarów czujnikami przyspieszeń. Przykładowo średnie maksymalne wartości bezwzględne przyspieszenia wyniosły:

- podczas siadania: 0,5 g według czujnika przyspieszeń $i 0,8 \mathrm{~g}$ według analizy obrazu

- podczas upadku: 2,8 g według czujnika przyspieszeń i 2,9 g według analizy obrazu.

\section{Podsumowanie}

Zastosowanie dwóch systemów pomiarowych - podstawowego, wykorzystującego akcelerometr i inklinometr, oraz dodatkowego, wykorzystującego kamery wideo i oprogramowanie do analizy obrazu - pozwoliło zarówno na porównanie otrzymanych wyników, jak i na zbadanie możliwości praktycznego zastosowania tych systemów. To porównanie, dotyczące tylko przedstawionych rozwiązań, pokazało dużą zbieżność mierzonych wartości, otrzymanych z czujników przyspieszeń i z analizy obrazu. Na stanowisku pracy nie można jednak zagwarantować obecności systemu kamer, które nie mogą być także noszone przez pracownika (system kamer z założenia nie był umieszczany na pracowniku). Poza tym wartości przyspieszenia i jego pochodnej są wyliczane pośrednio z pomiarów przemieszczenia wybranych punktów, co powoduje wzrost wielkości ewentualnych błędów pomiarowych. Problemem w przypadku kamer może być ponadto kwestia naruszenia prywatności osób monitorowanych.

Z opisanych powodów systemy pomiarowe zbudowane $z$ akcelerometrów i inklinometru, które umieszcza się na ciele człowieka, są w zdecydowanej większości przypadków znacznie lepszym rozwiązaniem technicznym, pozwalającym na identyfikację upadku człowieka na stanowisku pracy. Oczywiście w pewnych sytuacjach urządzenia te mogą generować fałszywy sygnał dotyczący rozpoczęcia spadania. Jest to jednak dopuszczalne i nie powoduje zmniejszenia poziomu bezpieczeństwa pracownika, ponieważ systemy pomiarowe nie wpływają bezpośrednio na samo powstrzymywanie spadania. Ich inicjacja wywołuje wcześniejsze uruchomienie sprzętu chroniącego przed upadkiem z wysokości, co wpływa na łagodniejszy przebieg powstrzymywania spadania.

Omówione systemy mogą także posłużyć jako elementy inicjujące urządzenia do dynamicznego skracania drogi spadania, które zmniejszą siły działające na człowieka podczas powstrzymywania jego spadania z wysokości. Istnieje też sprzęt chroniący przed upadkiem z wysokości, np. urządzenia 
Tabela1. Średnie maksymalne wartości bezwzględne pochylenia (kąta) w kierunku przód-tyłi bok-bok rejestrowane przy pomocy inklinometru Table 1. Average maximum absolute values of inclination (angle) in the anteroposterior and side-to-side directions recorded using an inclinometer

\begin{tabular}{|l|c|c|c|c|}
\hline \multirow{2}{*}{ Czynność } & \multicolumn{2}{|c|}{ Pochylenie w płaszczyźnie przód-tył } & \multicolumn{2}{c|}{ Pochylenie w płaszczyźnie bok-bok } \\
\cline { 2 - 5 } & średnia wartość [deg] & $\begin{array}{c}\text { odchylenie } \\
\text { standardowe [deg] }\end{array}$ & średnia wartość [deg] & $\begin{array}{c}\text { odchylenie } \\
\text { standardowe [deg] }\end{array}$ \\
\hline Siadanie & 17,25 & 1,63 & 1,75 & 0,68 \\
\hline Upadek & 80,00 & 0,00 & 9,20 & 3,49 \\
\hline
\end{tabular}

Tabela 2. Średnie maksymalne wartości przyspieszenia w kie runku góra-dół $(x)$ rejestrowane przy pomocy akcelerometru Table 2. Average maximum acceleration values in the up-down direction $(x)$ recorded using an accelerometer

\begin{tabular}{|l|c|c|}
\hline \multirow{2}{*}{ Czynnośćć } & \multicolumn{2}{|c|}{ Przyspieszenie w kierunku góra-dół(x) } \\
\cline { 2 - 3 } & $\begin{array}{c}\text { średnia skrajnych } \\
\text { wartości [g] }\end{array}$ & $\begin{array}{c}\text { odchylenie } \\
\text { standardowe [g] }\end{array}$ \\
\hline \multirow{2}{*}{ Siadanie } & 0,39 & 0,06 \\
\cline { 2 - 3 } & $-0,58$ & 0,07 \\
\hline \multirow{2}{*}{ Upadek } & 0,15 & 0,05 \\
\cline { 2 - 3 } & $-1,42$ & 0,16 \\
\hline
\end{tabular}

Tabela 4. Średnie maksymalne wartości narastania przyspie szenia w kierunku góra-dół $(x)$ rejestrowane przy pomocy akcelerometru

Table 4. Average maximum values of the increase in acceleration in the up-down direction $(x)$ recorded using an accelerometer

\begin{tabular}{|l|c|c|}
\hline \multirow{2}{*}{ Czynnośćc } & \multicolumn{2}{|c|}{$\begin{array}{c}\text { Narastanie przyspieszenia } \\
\text { w kierunku góra-dół }(\mathbf{x})\end{array}$} \\
\cline { 2 - 3 } & $\begin{array}{c}\text { średnia } \\
\text { skrajnych } \\
\text { wartości [g/s] }\end{array}$ & $\begin{array}{c}\text { odchylenie } \\
\text { standardowe } \\
\text { [g/s] }\end{array}$ \\
\hline \multirow{2}{*}{ Siadanie } & 6,26 & 0,40 \\
\cline { 2 - 3 } & $-4,94$ & 0,75 \\
\hline \multirow{2}{*}{ Upadek } & 6,96 & 1,18 \\
\cline { 2 - 3 } & $-12,26$ & 1,36 \\
\hline
\end{tabular}

samohamowne, które po niezbędnych modyfika cjach mogłyby zostać dostosowane do współpracy z systemami detekcji rozpoczęcia spadania. Tego typu podejście pozwoli na ograniczenie ewentualnych skutków powstrzymywania spadania i zminimalizowanie obrażeń ciała pracowników.

\section{BIBLIOGRAFIA}

[1] NOURY, N., et al. A proposal for the classification and evaluation of fall detectors. IRBM. 2008, 29(6): 340-349.

[2] CHUNG, M.C., et al. Posttraumatic stress disorder in older people after a fall. International Journal of Geriatric Psychiatry. 2009, 24(9): 955-964.

[3] SADIGH, S., et al. Falls and fall-related injuries among the elderly: a survey of residential-care facilities in a Swedish municipality. Journal of Community Health. 2004, 29(2): 129-140.

[4] SHUMWAY-COOK, A., et al. Falls in the medicare population: incidence, associated factors, and on health care. Physical Therapy. 2009, 89(4): 324-332 [5] ELLIOTT, S., PAINTER, J., HUDSON, S. Living alone and fall risk factors in community-dwelling middle age and older adults. Journal of Community Health 2009, 34(4): 301-310.

[6] YU, X. Approaches and principles of fall detection for elderly and patient. In: Proceedings of the $10^{\text {th }}$ IEEE International Conference on e-Health Networking, Applications and Service (HEALTHCOM'08). Singapore, July 2008, pp. 42-47.

[7] BOURKE, A.K., O'BRIEN, J.V., LYONS, G.M. Evaluation of a threshold-based tri-axial accelerometer
Tabela 3. Średnie maksymalne wartości przyspieszenia w kierunku przód-tył (y) rejestrowane przy pomocy akcelerometru Table 3. Average maximum values of forward-backward acceleration (y) recorded using an accelerometer

\begin{tabular}{|c|c|c|}
\hline \multirow[b]{2}{*}{ Czynność } & \multicolumn{2}{|c|}{ Przyspieszenie w kierunku przód-tył (y) } \\
\hline & $\begin{array}{c}\text { średnia skrajnych } \\
\text { wartości [g] }\end{array}$ & $\begin{array}{c}\text { odchylenie } \\
\text { standardowe [g] }\end{array}$ \\
\hline \multirow{2}{*}{ Siadanie } & 0,49 & 0,10 \\
\hline & $-0,20$ & 0,03 \\
\hline \multirow{2}{*}{ Upadek } & 0,07 & 0,03 \\
\hline & $-2,80$ & 0,22 \\
\hline
\end{tabular}

Tabela 5. Średnie maksymalne wartości narastania przyspieszenia w kierunku przód-tył $(y)$ rejestrowane przy pomocy akcelerometru Table 5. Average maximum values of the increase in acceleration in the forward-backward direction (y) recorded using an accelerometer

\begin{tabular}{|l|c|c|}
\hline \multirow{4}{*}{ Czynnośćc } & \multicolumn{2}{|c|}{$\begin{array}{c}\text { Narastanie przyspieszenia } \\
\text { w kierunku przód-tył (y) }\end{array}$} \\
\cline { 2 - 3 } & $\begin{array}{c}\text { średnia } \\
\text { skrajnych } \\
\text { wartości [g/s] }\end{array}$ & $\begin{array}{c}\text { odchylenie } \\
\text { standardowe } \\
\text { [g/s] }\end{array}$ \\
\hline \multirow{2}{*}{ Siadanie } & 3,46 & 0,57 \\
\cline { 2 - 3 } & 22,20 & 4,21 \\
\hline \multirow{2}{*}{ Upadek } & 22,20 & 1,13 \\
\cline { 2 - 3 } & $-26,20$ & 2,59 \\
\hline
\end{tabular}

fall detection algorithm. Gait \& Posture. 2007, 26(2): 194-199.

[8] KANGAS, M., et al. Comparison of low-com plexity fall detection algorithms for body attached accelerometers. Gait \& Posture. 2008, 28(2): 285-291. [9] NOURY, N., et al. Fall detection - principles and methods. In: Proceedings of the $29^{\text {th }}$ Annual International Conference on IEEE Engineering in Medicine and Biology Society. 2007, pp. 1663-1666.

[10] BOURKE, A.K., LYONS, G.M. A threshold-based fall-detection algorithm using a bi-axial gyroscope sensor. Medical Engineering \& Physics. 2008, 30(1): 84-90.

[11] KARANTONIS, D.M., et al. Implementation of a real-time human movement classifier using a triaxial accelerometer for ambulatory monitoring. IEEE Trans actions on Information Technology in Biomedicine. 2006, 10(1): 156-167.

[12] HWANG, J.Y., et al. Development of novel algorithm and real-time monitoring ambulatory system using Bluetooth module for fall detection in the elderly. In: Proceedings of the $26^{\text {th }}$ Annual International Conference of the IEEE Engineering in Medicine and Biology Society (EMBC'04). San Francisco, USA, September 2004, pp. 2204-2207.

[13] LUINGE, H.J., VELTINK, P.H. Inclination measurement of human movement using a3-D accelerometer with autocalibration. IEEE Transactions on Neural Systems and Rehabilitation Engineering. 2004 12(1): 112-121.

[14] ANANIA, G., et al. Development of a novel algorithm for human fall detection using wearable sensors.
In: Proceedings of the IEEE Sensors (SENSORS'08). Lecce, Italy, October 2008, pp. 1336-1339.

[15] MATHIE, M.J., et al. Accelerometry: providing an integrated, practical method for long-term, ambulatory monitoring of human movement. Physiological Measurement. 2004, 25(2): R1-20.

[16] WILLIAMS, G., et al. A smart fall and activity monitor for telecare applications. In: Proceedings of the $20^{\text {th }}$ Annual International Conference of the IEEE Engineering in Medicine and Biology Society. 1998. [17] DOUGHTY, K., LEWIS, R., MCINTOSH, A. The design of a practical and reliable fall detector for community and institutional telecare. Journal of Telemedicine and Telecare. 2000, 6(suppl. 1):150-154. [18] MATHIE, M., BASILAKIS, J., CELLER, B.G. A system for monitoring posture and physical activity using accelerometers. In: Proceedings of the $23^{\text {rd }}$ Annual International Conference of the IEEE Engineering in Medicine and Biology Society. Vol. 4. 2001.

[19] SALLEH, R., et al. Low power tri-axial ambulatory falls monitor. In: Proceedings of the $10^{\text {th }}$ International Conference on Biomedical Engineering. 2000.

[20] SIXSMITH, A., JOHNSON, N. A smart sensor to detect the falls of elderly. IEEE Pervasive Computing. 2004, 3: 42-47.

[21] FU, Z., et al. Fall detection using an address-event temporal contrast vision sensor. In: Proceedings of the IEEE International Symposium on Circuits and Systems. Seattle, Washington, USA, 2008, pp. 424-427.

[22] JANSEN, B., DEKLERCK, R. Context aware inactivity recognition for visual fall detection. In: Proceedings of the Pervasive Health Conference and Workshops. Innsbruck, Austria, 2006, pp. 1-4.

[23] MIAOU, S., SUNG, P., HUANG, C. A customized human fall detection system using omni-camera images and personal information. Proceedings of the $1^{\text {st }}$ Distributed Diagnosis and Home Healthcare Conference. Arlington, Virginia, 2006, pp. 39-42.

[24] ANDERSON, D., et al. Recognizing falls from silhouettes. In: Proceedings of the Annual International Conference of the IEEE Engineering in Medicine and Biology Society. 2006, pp. 6388-6391.

[25] ROUGIER, C. et al. Monocular 3D head tracking to detect falls of elderly people. In: Proceedings of the Annual International Conference of the IEEE Engineering in Medicine and Biology Society. 2006, pp. 6384-6387.

[26] CUCCHIARA, R., PRATI, A., VEZZANI, R. A multi-camera vision system for fall detection and alarm generation. Expert Systems. 2007, 24(5): 334-345. [27] MIAOU, S.-G., SUNG, P.-H., HUANG, C.-Y. A customized human fall detection system using omni-camera images and personal information. Distributed Diagnosis and Home Healthcare. 2006, pp. 39-42. [28] JANSEN, B., DEKLERCK, R. Context aware inactivity recognition for visual fall detection. In: Proceedings of the IEEE Pervasive Health Conference and Workshops. 2006, pp. 1-4.

[29] WAGNER, J. Regularised differentiation of measurement data in systems for healthcare-oriented monitoring of elderly persons. Rozprawa doktorska. Wrocław, 2020

Publikacja opracowana na podstawie wyników Vetapu programu wieloletniego pn. "Poprawa bezpieczeństwa i warunków pracy", finansowanego w latach 2020-2022 w zakresie badań naukowych i prac rozwojowych ze środków Narodowego Centrum Badań i Rozwoju.

Koordynator programu: Centralny Instytut Ochrony Pracy - Państwowy Instytut Badawczy. 